\title{
Cognitions on Competition: The Newcomers Impact
}

\author{
Raphaël Dornier (corresponding author) \\ Isc Paris \\ 22 Bd du Fort de Vaux, 75017 Paris, France
}

Tel: 33-1-40-53-99-99 E-mail: rdornier@iscparis.com

\author{
Noureddine Selmi \\ Groupe Sup de Co La Rochelle, 102 rue de Coureilles, Les Minimes \\ 17024 La Rochelle CEDEX - France \\ Tel: 33-5-46-51-77-00 E-mail: selmin@esc-larochelle.fr
}

Received: February 24, 2011

Accepted: June 4, 2011

doi:10.5539/ibr.v4n4p30

\begin{abstract}
A growing stream of research in the strategy field explores in a social constructionist approach the competitive structures of industries from the perspective of industry participants. This work has indeed demonstrated that managers tend to develop strategic group representations based on categorization processes in order to simplify and make sense of their competitive environment. However, in most cases these studies focused on mature industries facing few environmental upheavals or protected from external threats. The aim of this paper is to extend this line of research by examining, in an increasingly dynamic industry, how top managers consider, regarding their own historic strategic group knowledge structures, new types of firms entering their traditional domestic competitive space. The main result, consistent with the cognitive inertia hypothesis, is that top managers tend to rely on cognitive maps that reflect obsolete industry boundaries rather than on configurations taking into account new competitive threats.
\end{abstract}

Keywords: Strategic groups, Competition, Newcomers, Cognitive inertia

A growing stream of research in the strategy field explores in a social constructionist approach the competitive structures of industries from the perspective of industry participants. This work has indeed demonstrated that managers tend to develop strategic group representations based on categorization processes in order to simplify and make sense of their competitive environment. However, in most cases these studies focused on mature industries facing few environmental upheavals or protected from external threats. Moreover, they tended to consider only one level of the competitive environment and one period of time. The aim of this paper is to extend this line of research by examining, in an increasingly dynamic industry, how top managers consider, regarding their own historic strategic group knowledges structures, new types of firms entering their traditional domestic competitive space. Our objective, in line with the issue of homogeneity and inertia degree of competitive cognitions, will be to highlight and characterize the perceptions of French « traditional » outgoing tour-operators' managers regarding the development of new kinds of competitors on their domestic market. These modifications take place after a relative stable period of their competitive environment for these last ten years which succeeded to a huge crisis in the tourism industry triggered off by the Gulf war. We will mainly focus on the way they describe and insert these kinds of new actors in their existing competitive categorizations. If the literature seems to acknowledge that a stabilized sector should lead to a high homogeneity of managerial competitive cognitions, few was said about the perceptions homogeneity at the time of the arrival or growth of new actor types. Therefore, did tour-operators' managers include in their cognitive configurations these new actors? If so, do they regard them as forming major competitors, or do feel confident in considering them located in distinct competitive spaces? As convergent comments of experts and managers tended to point out that competitor analysis is not a strategic priority for tour-operators' CEOs, it seemed then stimulating to determine whether their competitive categorizations fit with the latest evolutions in this sector. To meet with Sutcliffe (1994), who noticed that surprisingly few empirical studies compared managerial cognitions of the environment with «objective» measures, we will thus be able to characterize this possible gap in the travel production sector.

\section{Cognitive firms grouping in a same industry}

As regards the industry analysis in terms of regroupings of companies sharing some similarities, two alternative conceptualizations have developed in the strategic management field, that is to say the strategic group and the cognitive group. 


\subsection{The two main concepts}

The first stream, coming from industrial organizations, began in 1972 with Hunt who identified three asymmetry sources between firms in the U.S. appliance industry, from which he distinguished four strategic groups and the entry barriers peculiar to each one. Afterwards, all the way through the seventies and eighties, other theoreticians used similar general principles to uncover in an industry groups of firms following a same strategy. Strategic groups were typically defined by the researcher, who used to have recourse to diverse series of financial and strategic variables, gathered from financial reports or other public information sources, to classify firms in strategic groups. Many theoreticians in this field implemented methodologies which ensured an homogeneity between firms belonging to a same group while preserving heterogeneity between firms belonging to distinct groups (ex: Caves \& Porter, 1977 ; Hatten, Schendel \& Cooper, 1978 ; Newman, 1978 ; Harrigan, 1983 ; Oster, 1982 ; Hawes \& Crittenden, 1984 ; Cool, 1985). Implicit in this approach to competitive positioning lies the hypothesis that such datas are able to capture in a pertinent way competition roots (Hodgkinson, 1997). Industrial environments would then be objective entities waiting to be revealed through formal analysis. Nevertheless, this stream, although it dominated during more than twenty years the major part of the literature on competition, was confronted with numerous criticisms by the end of the eighties. Hatten and Hatten (1987), for instance, pointed out that there could be no strategic groups in the absolute, as firms regroupings may only be analytical and conceptual constructs. Another major criticism directed at this stream, that is to say the absence of actors perceptions in the process of firms groupings, gave rise to a second stream of research coming from the cognitive approaches to strategy. The variables selected for the analysis by the theoreticians are indeed not necessarily the ones which guide decision making in the organizations and conduct the competition game (ex: Porac \& al., 1989 ; Barney \& Hoskisson, 1990 ; Porac \& Thomas, 1990 ; Calori \& al., 1992 ; Hodgkinson \& Johnson, 1994). Grisprud and Gronhaug (1985), for instance, discovered that the competitive structure perceived was instrumental in the determination of the strategy selected by retailers in a geographically defined market. It is thus now widely admitted that environment perceptions, rather than its « objective » characteristics, are the true determining factors of the strategic formulation process. The authors nourishing this stream therefore advocate that the structuring of an industry in groups of similar firms should be based on managers cognitive models, rather than on a statistical analysis of variables supposed to represent the industry key economic dimensions (Walton, 1986 ; Dutton \& Jackson, 1987). According to these theoreticians, managers' competitive representations are mainly based on a firms categorization process on the basis of their similarities and differences perceived (Porac \& al., 1987). A fundamental property of human mind would indeed be its ability to generate cognitive categories which resumes similarities and differences between objects, events, people and conditions in the environment (Holland \& al., 1986, Rosh, 1978, Smith \& Medin, 1981). Categorization activity then consists in aggregating and discriminating, in classifying elements from a population in homogeneous and significantly distinct categories that it is possible to describe in terms of characteristic properties or attributes. Rosch (1981) emphasized for his part that, even unconsciously, uncertainties relating to a particular case will be resolved by calling for information about other cases better known and regarded as similar, therefore causing grouping processes. As a result, Porac and Thomas (1990) argue that strategists act as organization taxonomists while trying to specify competitors by transcending the complexity of organizational forms in the environment. Cognitive group can then be viewed as gathering attributes perceived as common to the firms belonging to this group. This categorization process simplify for decision makers the complex cognitive problem consisting in analysing individually a large number of competitors. It is to be pointed out in this stream of research the work of Reger and Huff (1993), which enlightened that grouping of competitors is an operation " naturally » achieved by managers: « Our study suggests that strategic groups are readily perceived by strategists. The study thus provides evidence that strategic groups are more than analytical conveniences used by researchers; they are part of the way strategists organize and make sense of their competitive environment ». This psychological approach to the exploration of firms groups in an industry, which revitalized the literature on strategic groups, encouraged numerous studies. If the majority of the works following this research stream seemed to focus on the homogeneity of the competitive categorizations of managers working in a same industry, two other kinds of works were interested in a close or even complementary issue, that is to say the stability of competitive cognitions and their congruence with assessments of the competitive environment regarded as objectives.

\subsection{Homogeneity of competitive cognitions}

The first studies on competitive cognitions, mostly pionnered by Porac and his colleagues on the Scottish knitwear industry since 1989, tended to demonstrate a high homogeneity of managers' cognitive schemes in a same industry. This homogeneity could embrace all the groups of firms identified by the CEOs (Reger \& Huff, 1993) or be restricted to the sole organizations regarded as competitors (Hodgkinson \& Johnson, 1994). Porac and his colleagues (1995) for instance, drew up a cognitive model shared by nearly all managers which consisted in six organizational 
forms based on such attributes as size of the firm, technology, product type and geographical location. These authors identified numerous factors likely to encourage an homogenization process of the competitive categorizations identified by managers. This cognitive homogeneity could mostly be the result of the fact that in any given industry actors interact within conventions and trade associations (Starbuck, 1975), take part in similar training programs and are exposed to common environments (Abrahamson \& Fombrun, 1994; Porac \& al., 1989). They also share the same information sources, like trade journals, and sometimes the same consultants and executives (Calori \& Sarnin, 1995). Factors like the presence in an industry of charismatic leaders, likely to spread their own perceptions, the similarity of the educational programmes followed by managers and mutual work experiences can also contribute to reinforce this homogenization process of competitive cognitions (James, 2000). The whole of these interaction processes (Eden \& Radford, 1990), described as socio-cognitive (Ginsberg, 1990), foster then the combination of individual cognitive competitive schemes to lead to very similar or shared competitive space mental models. Other studies, on the contrary, tended to demonstrate an heterogeneity of cognitive competitive categorizations between industry participants (ex: de Chernatony et al., 1993 ; Johnson \& al., 1998 ; Reger, 1990). The datas collected by Grisprud and Gronhaug (1985) highlighted the existence of some competitive cognitions variety in a geographically relatively narrow market. Similarly, Daniels and his colleagues (1994) observed a diversity of individual cognitive schemes in a same industry, as well as Calori and Sarnin (1995) in a study revealing the competitive cognitions of managers from different nationalities operating in the automobile industry. Hodgkinson et Johnson (1994), for their part, showed that heterogeneity of cognitions, although real at the industry level regarding both the competitive categories identified and the richness of their descriptions, was less obvious between managers sharing a same function and/or working in a same company. Although few theoreticians explicitly focused on the antecedents of cognitions heterogeneity, some of them identified propitious conditions for such phenomenon at the inter-organizational and intra-organizational levels (Narayanan \& Kemmerer, 2001). At the inter-organizational level, heterogeneity would be more likely in turbulent environments (Reger \& Palmer, 1996), during the first stages of the industry formation and in markets characterized by a diversity of products, consumers and technologies (Easton \& al., 1993). On the other hand, as industries evolve through their life cycles, managers' cognitive models of the competitive space would become increasingly stable and similar ((Levenhagen \& al. 1993). National culture also affects the interpretations and responses of managers regarding strategic issues (Calori \& al., 1992; Schneider $\&$ de Meyer, 1991). At the intra-organizational level, it was emphasized that managers' world views are shaped, at least partly, by their carrers (ex: Bouchet, 1976; Gunz, 1989; Hambrick \& Mason, 1984 ; Whitley, 1987). As mental models are determined by experience (Schoenfeld \& Herrman, 1982) and by the belonging company specificities, it may seem legitimate to consider the possibility of divergences between individual mental models of competition (Daniels \& al., 1994). Managers, in different roles, indeed face specific environmental contingencies, at least in terms of context, function and responsibility levels (Lawrence \& Lorsch, 1967). Beyond the identification of factors likely to explain variations in terms of homogeneity of competitive categorizations discussed in different studies, some authors, and mostly Hodgkinson, wondered about the possible methodological biases and holes existing in this literature stream. One problem the authors trying to establish to which extent managers mental models are homogeneous are confronted with lies in the difficulty to compare a mental model with another, both regarding their structure and their content (Hodgkinson, 1997). In fact, homogeneity or heterogeneity were assessed in the literature at different levels. For instance, whereas some estimate the homogeneity regarding the dimensions used by managers to categorize competitors (ex: Reger, 1990), others focus on the content of resulting categories (ex: Reger \& Huff, 1993). Moreover, according to Hodgkinson (1997), most of the studies which discovered diverse mental models of competitive structures tended to use methodologies which, by their own nature, may have accentuated surface differences at the expense of underlying similarities.

\subsection{Stability of competitive cognitions}

While some theoreticians (ex: Barr \& al., 1992 ; Bartunek, 1984 ; Fahey \& Narayanan, 1989 ; Fletcher \& Huff, 1990 ; Huff \& Schwenck, 1990 ; Laughlin, 1991 ; Narayanan \& Fahey, 1990) explored cognitive change processes in a variety of domains, only three studies focused on the stability of cognitive competitive categorizations over a limited period. These three studies, carried out by Gronhaug and Falkenberg (1989), Reger and Palmer (1996) and Hodgkinson (1997), used a longitudinal research design and concentrated on industries experiencing environmental upheavals of distinct natures. They all leaded to similar results, that is to say a high stability of cognitive competitive categorizations. These perceptions seemed then not to fit any more with the market economic realities, as evaluated by outward experts. Such results therefore tie up with conclusions of numerous studies which revealed wide errors and biases in cognitions (Kahneman \& Tversky, 1973 ; Kiesler \& Sproull, 1982 ; Lant, Milliken \& Batra, 1992). Population ecology theoreticians like Hannan et Freeman (1989) postulated that inertia forces often prevent organizations from adapting to changing environments. As Porac and Thomas (1990) pointed out, a possible source of such weak flexibility derives from the cognitive inertia peculiar to managers. Managers, as transactions in the 
market stabilize, become indeed increasingly dependant on the shared mental models which came to prevail. The notion of cognitive inertia therefore involves to a certain extent that firms experiencing difficulties may perpetuate them due to the inability of their managers to revise their mental models of the competitive space quickly enough to adapt to a moving environment (Hodgkinson, 1997a). In line with this general issue of competitive cognitions homogeneity and their congruence with environmental upheavals, we selected as our empirical field the french outgoing tour-operating industry, mostly due to the significant competitive modifications it experienced these last years and to the weak number of studies focusing on this complex sector.

\section{Methodology}

\subsection{The French outgoing tour-operating competitive system}

The French outgoing tour-operating sector seems to exhibit two main characteristics, identified both by managers and experts: its fragmented nature, with nearly 360 actors, and an a weak average profitability, a situation which favours acquisitions and mergers leaded mostly by English and German tour-operators. The tour-operator, which production is generally marketed through travel agencies, is the emblematic actor in this sector, as its main activity is precisely to combine the different elements making up packaged or inclusive tours. Its position is therefore central in the field of tourism, as it is linked both with actors located upstream like hotelkeepers and airways companies and actors located downstream like travel agencies or end customers. Some companies have overshadowed for the last decades the French tour-operating sector by their seniority, reputation and size. The two main ones, which are leaders in terms of turnover, are Nouvelles Frontières and Le Club Méditerranée. The former has an important activity of air travels only sales, while the latter is more regarded as managing an hotel network rather than being a genuine tour-operator. Besides these two main historic figures or French tourism coexist nearly 360 tour-operators, more or less specializing on activities like trekking or on travel destinations like Turkey. For these last few years, three main kinds of actors have intensified their presence in the French tour-operating market. The first actor type is made of foreign tour-operators, mostly German and English ones. These tour-operators, due in particular to the specificity of their respective domestic markets, enjoy a size well superior to the one of the first French tour-operators. TUI's turnover, for instance, which is the leading tour-operator on the German market, is thus ten times larger than the one of Nouvelles Frontières. It is nevertheless to be noticed that the penetration of foreign tour-operators on the French market is mainly limited to taking stakes in french companies, sometimes majority ones, but they do not actually endanger domestic tour-operators' identity, as these latter ones retain their brands and production specificity. The second actor category consists in organizations which specialized on travel sales on line. These companies, like for instance Karavel or Lastminute, focused their strategy mostly on the internet media and penetrated the travel sector by this means. These only-internet based actors are, for most of them, independent and therefore not legally or financially linked with specific tour-operators. If their original activity is the distribution via internet of air travels or travel packages designed by organizations specializing on tour-operating, mostly in the case of trips sold at the last minute, some of them attempt to develop their own production activity. As almost all tour-operators described as « traditional » tend to develop their own web site aimed at marketing their production, it therefore seems that it is for the best interest of these web specialists to reduce their dependence towards these suppliers by directly negotiating with contractors located upstream the tourism field like airways companies or hotel networks. Lastly, the third type of actors consists in mass merchandisers like Leclerc or Carrefour. These large-scale distribution actors, which originally did not offer packaged tours, turned to this range of products at the beginning of the nineties and since then kept on developing this activity. Some analysts thus consider that large-scale distribution could represent nearly $30 \%$ of the total travel sales on the French market by the year 2005 (Secrétariat d'Etat Français au Tourisme, 2002). Even if the production activity of this organizational type is delicate to measure, their financial power and their ability to generate high volumes for a same kind of product could lead them to increasingly develop this activity. To complete this overview, it is to be stressed that the French tour-operating sector seems to represent a typical case of a close field likely to develop its own competitive recipe. We can indeed list some factors encouraging a high interaction level between tour-operators managers: nearly $80 \%$ of all French outgoing tour-operators are located on the Parisian area, its trade association gather an important number of organizations and many managers completed their entire career in this sector after following tourism studies. Nevertheless, we suspect that we will also find some differences in competitive cognitions as many tour-operators hold strong identities and as this sector is attractive for young entrepreneurs not yet exposed to collective representations.

\subsection{Sample}

We interviewed only CEOs, marketing directors or sales directors from a high diversity of tour-operators in terms of size and product range specificity. Strategic management theoreticians indeed argue that a crucial role in competitive dynamics is played by key managers who scan rival organizations and draw up strategies aimed at 
improving firm performance (Porter, 1980; Rumelt, 1987). Hambrick and Mason (1984) similarly pointed out that strategic decisions are affected by top executives cognitive models. Lyles et Schwenk (1992), for their part, stressed that decision-makers have a huge influence on the development of organizational knowledge structures as they are the ones who initially interpret the importance of environmental events and disseminate their perceptions about environment structure by their speeches and comments. We therefore interviewed 43 top managers belonging to 42 distinct «traditional» tour-operators. Interviews were conducted at the interviewee's office after a brief and deliberately vague description of the study objectives was given. All interviews were recorded and afterwards retranscribed. The interviews, which took place between April and December 2001, lasted on average 45 minutes. Our sample consisted in 2 non-specialized tour-operators and 41 specialized tour-operators. As according to most managers interviewed less than 10 outgoing tour-operators could be regarded as non-specialized on the french market, whereas 350 could be considered specialized, the structure of our sample in terms of specialization degree could be seen as satisfactory.

\subsection{Data Collection}

We questionned tour-operators' managers concerning two levels of their competitive environment. The first level refers to the whole population of organizations having a packaged travel production activity and operating on the French market, except those organizations specializing only on a receptive activity or on business trips. We thus focused on the way they categorize the organizations making up this population. We described this cognition kind, which is supposed to take into account the whole of a given population sharing a same activity, as "wide competitive cognition ». The second level relates only to those organizations that managers identify as competing with their own company. We take then an interest in the way they identify and categorize these perceived competitors. This type of cognition, much more restricted in the scope of the organizations taken into consideration, will be described as "close competitive cognition». Besides this double dimension of the field covered by competitive cognitions, we also introduced a double temporal dimension. Managers are indeed asked to identify organizational categories not only in their wide and close competitive environments, but also currently and by the year 2005. It seemed interesting to consider a long term perspective in our study, as most works on strategic and cognitive groups tended to give priority to a retrospective or current point of view. A three years temporal horizon was considered as most managers, during preliminary interviews, revealed that it corresponded to the maximum period of time they felt at ease to forecast. Therefore, if managers did not yet integrate new actors in their competitive cognitions regarding the current market, they could be doing so concerning their anticipations of their competitive environment as it would be structured in 2005. We used an interview guide focusing on three major topics: identifying and characterizing the different groups of outgoing travel producers currently and by the year 2005, identifying and characterizing the different groups of outgoing travel producers currently and by the year 2005, characterizing the three new kinds of travel producers currently and by the year 2005. If the first two topics gave priority to a cognitive process close to the automatic mode (Reger \& Palmer, 1996), as the techniques used were non-directive and induced spontaneous answers, the third topic, for his part, induced a cognitive process getting close to the controlled mode (Reger \& Palmer, 1996). We specify that each content of the third theme was introduced only in case it was not previously spontaneously mentioned. Following the works leaded by Porac and his colleagues, the hierarchical taxonomy technique was used to elicit managers' categorizations regarding the whole population of organizations developing an outgoing travel production. This procedure lies on a considerable knowledge body suggesting that cognitive categories can be organized in a hierarchical way (Rosch, 1978). By this approach, managers are induced to identify sub-categories emanating from a starting one. Once the first level categories identified, managers are then asked to reveal new sub-categories emanating from these first level categories. We specify that we wished to restrict these taxonomies to two sub-levels. Indeed, for time constraints and as the distinctions within categories of outgoing travel producers elicited could be in the absolute carried out until obtaining as many categories as tour-operators on the French market, it seemed preferable to stop the subdivision exercise at this stage. In line with Porac, we redrawed this subdivision process in front of the manager who thus was free to modify or complete his answers as the session was going ahead. In case the manager did not spontaneously mention companies belonging to each of the group identified, we then asked him to do so. After eliciting managers' taxonomies regarding their current competitive environment, we then asked them to determine which possible modifications this taxonomy would experiment by the year 2005 , considering both the categories identified and their content. For collecting cognitions relating to the close competitive environment, we had recourse to the "visual card sorting technique ", mostly used by Calori and his colleagues in the strategic management field. The "visual card sorting technique » is a method derived from the "full context form » of the Kelly's repertory grids (Calori \& Sarnin, 1995; Daniels et al., 1995), which does not presuppose the cognitive structures of the interviewee. Using this procedure we asked managers to gather in same groups, that he will have to describe, the organizations they identified as competitors. Managers were then induced to identify what will be the possible 
modifications in the structure and content of theses groups by the year 2005. After collecting managers' cognitions in a spontaneous mode considering their wide, close, current and anticipated competitive environments, we then asked them, at the end of the interview, to characterize each of the three newcomers types, in case they did not previously mention them. This assisted characterization is encouraged by asking the two following questions:

In which ways this type of actors gets inserted in the taxonomy you previously identified, currently and by the year 2005 ?

Does this type of actors represent an opportunity, a threat or has no impact on your company, currently and by the year 2005 ?

\subsection{Data analysis}

We distinguished in our analysis the two levels of competitive environment previously described. In order to include also the dimensions relating to the time period considered (currently and by the year 2005) and the type of answer induced (spontaneous or assisted), we then classified the managers replies regarding the three types of newcomers identified according to a grid comprising five levels. These levels refers to a descending integration of new entrants in cognitive categorizations. This grid, concerning the wide competitive environment, and which is to be applied for current and anticipated cognitions, was the following:

The newcomers category is spontaneously explicitly mentioned in the hierarchical taxonomy.

One or some members of the newcomers category are spontaneously inserted in a larger category in the hierarchical taxonomy.

The newcomers category is considered, in an assisted mode, a meaningful category and is added to the hierarchical taxonomy

One or some newcomers are, in an assisted mode, inserted in a category previously spontaneously identified in the hierarchical taxonomy.

The newcomers category is regarded, in an assisted mode, as not belonging to the outgoing tour-operators competitive system.

Concerning the close competitive environment, our analysis grid, to be applied also to current and anticipated cognitions, was the following:

One or some newcomers are spontaneously mentioned as competitors forming an exclusive category.

One or some newcomers are spontaneously mentioned as competitors but not forming an exclusive category.

One or some newcomers are spontaneously considered secondary competitors.

One or some newcomers are considered, in an assisted mode, secondary competitors.

No newcomer is regarded, in an assisted mode, as a secondary competitor.

As each grid is to be applied twice for each type of cognition (one time for cognition of current environment and one time for cognition of the environment by the year 2005), the maximum score for a certain kind of newcomers would then be 20. This score would correspond to a total no-integration of new competitors kinds in a particular competitive representation. An important methodological pitfall arises from the case of foreign tour-operators. Indeed, in case is mentioned during the interview a company hold by a foreign tour-operator but which maintains its own brand and product range, is it preferable to consider this company belonging to the foreign tour-operators' category? Our choice was then to consider refering to this category only the sole companies which had explicitely been characterized by the managers as possessed by foreign tour-operators. It indeed seemed possible that a manager could not be aware of the ownership structure of the company he mentioned.

\section{Results}

Average scores concerning the different newcomers categorizations are the following:

Insert table 1

As for wide competitive cognitions, it is to be noticed that these three actors types are far from being systematically regarded as belonging to the tour-operators global competitive system. Some managers indeed argued that only-web based operators and large-scale retailers have not and will not have, for the next three years, the capacity to develop a significant outgoing travel production activity. Now, it is to be stressed that some organizations belonging to these two categories have actually began to develop a production activity, even if its extent is difficult to assess. Nevertheless, we have to mention that anticipated cognitions average scores are better than current cognitions ones, but the difference remains weak. These results therefore seem to corroborate a phenomenon pointed out by cognitive 
theory, that is to say the exceptional nature of changes anticipations in mental models (Fiske et Taylor, 1984). If we now have a look at the extreme cases, the manager who integrated to the maximum these newcomers in its wide cognitive categorizations presents a 1,7 average score. This manager thus spontaneously cited foreign tour-operators and only-web based organizations categories in its hierarchical taxonomy, while identifying mass merchandisers as forming a meaningful category only in an assisted mode. The five managers with the best integration scores present a 2,6 average score. The newcomers impact on wide competitive categorizations was the weakest for a manager showing a 4,7 score. The average score of the five managers presenting the highest scores is 4,14. Foreign tour-operators category is, relatively to the other two new entrants categories, the most frequently characterized as belonging to the travel producers' competitive system on the French market. Nevertheless, its average score is only 3,1 . The manager who integrated at the maximum this category in its cognitive configuration presents an average score of 1 , while the average score for the five managers who integrated most this category is 1,4 . The manager who the least integrated this category in its cognition presents for his part an average score of 5 , while the average score for the five managers presenting the highest scores is 4,1 . Only-web based organizations category was frequently regarded as not being a meaningful travel producers category. The main raison mentioned was that these organizations mostly market air travels or packaged trips developed by « traditional » tour-operators. It is interesting to notice that managers interviewed anticipated some weakening of the organizations belonging to this category in the next three years. Many of them felt indeed that these kind of organizations will not be able to acquire the necessary competencies for working as tour-operators. They would therefore not get the capacity to compete with « traditional » tour-operators which increasingly develop their own web-sites. These organizations born on the web would thus retain as their unique activity last minute trip sales, that it to say packaged tours that «traditional» tour-operators did not make it to sell within their planned deadlines. Only two managers did spontaneously position this category in their hierarchical taxonomies. On the contrary, eleven managers did not regard this category as forming a meaningful category of packaged trips producers, even in an assisted mode. Large-scale distribution, just like only-web based organizations, do not really get a recognition as trip producers. Most managers indeed argued that the interest of mass merchandisers is to remain distributors of tourism products combined by " traditional » tour-operators. No manager did spontaneously mention this category in its wide competitive cognitions, while twelve managers did not consider for their part this category as forming a meaningful packaged trips producers category. In addition, some managers have, in order to illustrate this supposed inability of organizations not coming from the tourism universe to succeed within this organizational field, mentioned the case of some banks which a few years ago were to cease their diversification in this field as they did not reach satisfactory profitability levels. It is clear in our results that tour-operators' managers in no way tended to consider these new types of actors main or secondary competitors. That is especially the case for only web-based organizations and large-scale retailers categories. Only three managers spontaneously mentionned foreign tour-operators as forming a meaningful category of competitors to their own organizations. The raisons adduced by many managers with regard to this no-identification of foreign tour-operators as competitors is mostly due to their non-specialized positioning. Managers also point out that french customers are so specific that they present demand levels higher than the ones of English or German customers. This cultural gap would therefore enable French tour-operators, and mostly those speciazed on a market niche and offering made-to-measure services, to be sheltered from foreign tour-operators considered trip industrialits with a standardized production. Only two managers did regard only-web based organizations as forming a specific category of current competitors. It is nevertheless to be noticed that one of these two managers foresaw the disappearance of this competitor category by the year 2005 . The reasons mentioned are mostly linked with the inability of this organizational type of to offer a personalized relationship with customers, which reflects an inappropriateness of this tool for trip sales integrating an advice dimension. Moreover, managers interviewed tended to consider more these web-based organizations an additional distribution channel which gives them the opportunity to reach a wider range of potential customers. Managers also did frequently stress the financial difficulties met by this type of actors. These obstacles would then prevent them from developing a genuine production activity. It is noteworthy that only two managers named mass merchandisers as main competitors, which were inserted in a category made of non-specialized tour-operators offering standardized trips at cut-off prices. Managers seemed therefore to consider that large-scale distributors are and will not be interested in packaged trips likely to attract only few customers, like diving trips for instance. Their strategy would then to give priority to large sales volumes, mostly through hotel stays in France or in the Mediterranean area. If we now consider simultaneously managers' cognitions regarding the two analysis levels of the competitive environment mentionned, it is to be noticed that they do not seem to have been reviewed by the growing stake of these new actors kinds. Moreover, it is to be pointed out that managers tended to identify as competitors only those organizations which belonged to a same category in the hierarchical taxonomy. Thus, in most cases, competitors were clearly positioned in one of the categories forming the third level of the hierarchical taxonomy. This results therefore reveals a high interdependence 
between these two perceptions levels of the competitive field. This finding ties up with the results of Porac and his colleagues $(1989,1995)$ who used the term of inflexion point to characterize the level in the hierarchical taxonomy from which managers start to identify competitors. It is therefore hardly surprising that organizations which were not yet cognitively integrated into the wide competitive field level were not considered current or potential competitors.

\section{Discussion}

\subsection{Some explanations about these weak consideration of newcomers}

The surprising weak level of newcomers integration in cognitive categorizations may be explained by a series of factors associated with the specificity of the sector under study. Concerning the wide competitive environment representations, it is to be noticed that the sole population of tour-operators considered «traditional», that is to say presenting similar organizational profiles, consist in no less than 360 members. Some managers thus did emphasize discovering new tour-operators everyday while adding that numerous others also disappear at regular intervals. Such quantity of actors may therefore be likely to discourage any information search on competition. Moreover, many managers pointed out that competition scanning is in no way one of their strategic priorities. As located at the heart of the tourism field, tour-operators' managers may then be focusing on a vertical logic to the extent that they ignore actors likely to penetrate their competitive space. Moreover, many tour-operators, a characteristic that we clearly found in our sample, are small structures specializing on market niches. These actors market an offer very targetted on a destination or trip theme and therefore regard as belonging to their pertinent competitive space only the few other organizations showing nearly the same positioning. It is thus noteworthy that most managers cited less than 7 competitors, which were gathered in two or three distinct groups. Now, the three major new actors types identified have clearly a non-specialized positioning. Nevertheless, their positioning could be changing in the next three years, once they achieved to settle at the expected level on the french market. Another point to be mentioned relates to the sharp distinction which was often made between the different groups of «traditional » tour-operators. It stood out clearly from the comments made by managers from small specialized tour-operators that they felt as extremely distant from the world of non-specialized large firms like Nouvelles Frontières or Fram. The choice of the terms used by these same managers to characterize these two main categories is from this perspective revealing: trip industrialists and trip artisans. The perception of such a gap between two kinds of organizations sharing yet some similarities might explain why a rift even wider could arise concerning the characterization of newcomers showing distinct organizational forms.

\subsection{Some methodological limits}

As our identification of competitive upheavals was limited to three new competitor kinds, we neglected other competitor categories likely to be taken into account by the managers interviewed. Some managers thus reported a new competition coming from foreign receptive organizations, not to say the one originating from hotels or airlines which are now able, due notably to the internet, to directly get in touch with end consumers. Potential tourists enjoy then growing possibilities to by-pass packaged tours as marketed by tour-operatours to assemble by themselves the different parts of their trips. The identification mode of competitive categories and main competitors might also have largely affected our results. We could indeed distinguish two identification and characterization of competitors procedures. With the first one managers are to name their competitors in reply to an open question (De Chernatony \& al., 1993 ; Griprud \& Gronhaug, 1985), whereas with the second one managers are given a list of firms to consider (Porac \& al., 1995). Now, our methodology favoured a spontaneous quotation of competitors, a task which naturally generate a shorter list of competitors than a recognition task. This methodological choice then biased our results towards a narrowing of perceived categories and competitors (Clark \& Montgomery, 1999). Nevertheless, we believe that this procedure is theoretically the most adequate, as it generates a list of the competitors most accessible in memory, that is to say the competitors that managers are likely to consider in their everyday activities. Concerning the characterization of the supposed link between competitive perception and professional career, it would certainly have been preferable to introduce an intermediate variable which would have been firm positioning. Maybe then we would have been able to identify sharp distinctions between the cognitions of managers belonging to tour-operateurs showing the same competitive positioning, but who followed different careers.

\subsection{Implications for tour-operators' managers}

The fact of identifying few competitors and ignoring some organizations kinds in a wide competitive field may lead to prejudicial consequences for a tour-operator. Moreover, most tour-operators did not seem to have identified potential competitors, despite the fact that detecting new threats in the medium and long run is a strategic matter. Stories of managers who thought perfectly mastering their competitive field and who were then surprised by the arrival of a new competitor operating in a radical distinct way are indeed many (ex: Slywotzky, 1996). Furthermore, 
cognitive inertia, by limiting the understanding degree of environmental modifications, is likely to impede organizational change. Tour-operators' managers should be in the first place aware that their mental models based on historic categories are probably inadequate representations in a moving environment. They should then periodically get into individual and collective reflection processes in order to consider to which extent their hypothesis and beliefs about their competitive environment give them a viable base on which they can build efficient strategies (ex: Bowman \& Johnson, 1992 ; Huff, 1990 ; Mitroff, 1988). Their individual cognitions might then be enhanced or even surpassed by an active and regular search of diverse visions and by the adoption of formal decision making processes aimed at identifying and characterizing competitors. Tour-operators could also recruit more managers coming from sectors not linked with the tourism field (Barr et al., 1992; Nystrom et Starbuck, 1984). Managers should also focus more on their competitors as they are defined by consumers (Clark \& Montgomery, 1999). Competitors in our data tended indeed to be described in terms of supply side attributes like product specificity or integration in the tourism field. Now, it is not clear whether potential consumers of packaged tours will not regard as competitors a large-scale distributor and a «traditional» tour-operator specializing on a particular destination.

\subsection{Research perspectives}

If our study focused on the competitive cognitions of managers working in «traditional » tour-operators regarding new actors, it would also be instructive to enlighten the competitive cognitions of managers coming from these new entities. We may indeed wonder whether they consider « traditional» tour-operators competitors, or whether they have also the tendency to restrict their competitive space to the sole companies showing similar organizational profiles. Some exploratory interviews with managers working in only-web based organizations lead us to think that this last proposition would be confirmed. We should also broaden the scope of our study in order to explain the nature of the environmental changes which trigger cognitive adjustments. It would thus be possible to asses to which extent the type, the intensity or the rhythm of competitive modifications affect cognitive categorizations, and how new environmental information are processed. Environmental changes perceived as negative, drastic or sudden will indeed probably result in cognitive models adjustments different from those emanating from positive, gradual and minor changes (Dutton, 1993). To be able to answer these questions subsequent studies should favour longitudinal designs combining a higher sophistication of analytical methods and larger sample sizes (Hodgkinson, 1997).

\section{References}

Abrahamson, E. \& Fombrun, C.J. (1994).Macrocultures: Determinants and Consequences. Academy of Management Review, 19 (4).: 728-755.

Barney, J.B., \& Hoskisson, R.E. (1990).Strategic Groups: Untested assertions and research proposals. Managerial and Decision Economics, 11: 187-198. doi:10.1002/mde.4090110306, http://dx.doi.org/10.1002/mde.4090110306

Barr, P.S., Stimpert, J.L. \& Huff, A.S. (1992).Cognitive Change, Strategic Action and Organizational Renewal. Strategic Management Journal, 13 (Special Issue: Summer).: 15-36.

Bartunek, J.M. (1984).Changing interpretative schemes and organizational restructuring: the example of a religious order. Administrative Science Quaterly, 29: 355-372. doi:10.2307/2393029, http://dx.doi.org/10.2307/2393029

Bowman, C., \& Johnson, G. (1992).Surfacing Competitive Strategies. European Management Journal, 10(2).: 210-219. doi:10.1016/0263-2373(92)90071-B, http://dx.doi.org/10.1016/0263-2373(92)90071-B

Calori, R., Johnson, G., \& Sarnin P. (1994).CEOs' cognitive maps and the scope of the organization. Strategic Management Journal, 15: 437-457. doi:10.1002/smj.4250150603, http://dx.doi.org/10.1002/smj.4250150603

Calori, R., Johnson, G., \& Sarnin, P. (1992).French and British Top Managers' Understanding of the Structure and the Dynamics of their Industries: A Cognitive Analysis and Comparison. British Journal of Management, 3: 61-78. doi:10.1111/j.1467-8551.1992.tb00036.x, http://dx.doi.org/10.1111/j.1467-8551.1992.tb00036.x

Caves, R. \& Porter, M.E. (1977).From entry barriers to mobility barriers. Quaterly Journal of Economics, 91: 421-41. doi:10.2307/1885416, http://dx.doi.org/10.2307/1885416

Clark, B.H., \& Montgomery, D.B. (1999).Managerial Identification of Competitors. Journal of Marketing, 63: 67-83. doi:10.2307/1251776, http://dx.doi.org/10.2307/1251776

Collins, A.M., \& Loftus, E.F. (1975).A spreading-activation theory of semantic processing. Psychological Review, 82: 407-428. doi:10.1037/0033-295X.82.6.407, http://dx.doi.org/10.1037/0033-295X.82.6.407

Cool, K. (1985).Strategic group formation and strategic group shifts: A longitudinal analysis of the US pharmaceutical industry. 1963-82, PhD Dissertation, Purdue University.

Daniels, K., de Chernatony, L., \& Johnson, G.. (1993).Mapping Managers' Mental Models of Competitive Industry Structures. Paper presented to the Occupational Psychology Conference, Brighton. 
De Chernatony, L., Daniels, K., \& Johnson, G. (1993).A cognitive perspective on managers' perceptions of competition. Journal of Marketing Management, 10: 373-381. doi:10.1080/0267257X.1993.9964246, http://dx.doi.org/10.1080/0267257X.1993.9964246

Dutton, J.E. (1993).Interpretations on automatic: A different view of Strategic issue diagnosis. Journal of Management $\quad$ Studies, 30 : 339-357. doi:10.1111/j.1467-6486.1993.tb00308.x, http://dx.doi.org/10.1111/j.1467-6486.1993.tb00308.x

Dutton, J.E., \& Jackson, S.E. (1987).Categorizing strategic issues: Links to organizational action. Academy of Management Review, 12: 76-90.

Easton, G., Burrell, G., Rothschild, R., \& Shearman C. (1993).Managers and Competition. Oxford: Blackwell.

Eden, C., \& Radford, J. (1990).Tackling Strategic Problems: The Role of Group Decision Support. London: Sage.

Fahey, L., \& Narayanan, V.K. (1989).Linking changes in revealed causal maps and environmental change: An Empirical Study. Journal of Management Studies, 26: 361-378. doi:10.1111/j.1467-6486.1989.tb00734.x, http://dx.doi.org/10.1111/j.1467-6486.1989.tb00734.x

Fiegenbaum, A., \& Thomas, H. (1988).Attitudes toward risk and the risk-return paradox: prospect theory explanation, Academy of Management Journal, 31: 85-106. doi:10.2307/256499, http://dx.doi.org/10.2307/256499

Fiske, S. \& Taylor, S. (1984).Social Cognition. Addison-Wesley: USA.

Fletcher, K.E., \& Huff, A.S. (1990).Strategic argument mapping: A study of strategy reformulation at AT\&T. In A.S. Huff (Ed.), Mapping Strategic Thought: 165-193. Chichester: Wiley.

Gammack, J.G. (1987).Modelling Expert Knowledge Using Cognitively Compatible Structures. In The Proceedings of the Third International Expert Systems Conference, Learned information: Oxford.

Ginsberg, A. (1990).Connecting diversification to performance: A socio-cognitive approach. Academy of Management Review, 15: 514-535.

Grisprud, G., \& Gronhaug, K. (1985).Structure and strategy in grocery retailing: A sociometric approach. Journal of Industrial Economics, 33: 339-347. doi:10.2307/2098541, http://dx.doi.org/10.2307/2098541

Gronhaug, K., \& Falkenberg, J.S. (1989).Exploring strategy perceptions in changing environments. Journal of Management Studies, 26: 349-359. doi:10.1111/j.1467-6486.1989.tb00733.x, http://dx.doi.org/10.1111/j.1467-6486.1989.tb00733.x

Gunz, H. (1989).The dual meaning of managerial carrers: Organisational and individual levels of analysis. Journal of Management Studies, 26(3).: 225-250. doi:10.1111/j.1467-6486.1989.tb00726.x, http://dx.doi.org/10.1111/j.1467-6486.1989.tb00726.x

Hambrick, D.C., \& Mason, A.C. (1984).Upper echelons: The organization as a reflection of its top management. Academy of Management Review, 9: 193-206.

Hannan, M.T., \& Freeman. J.H. (1989).Organizational Ecology. Harvard University Press, Cambridge: MA.

Harrigan, K. (1983).An application for clustering for strategic group analysis. Working Paper, Columbia University, New York.

Hatten, K.J., \& Hatten, M.L. (1987).Strategic groups, Asymmetrical Barriers and Contestability. Strategic Management Journal, 8(4).: 329: 342.

Hatten, K., Schendel, D., \& Cooper, A. (1978).A strategic model of the U.S. brewing industry: 1952-1971. Academy of Management Journal, 21: 592-610. doi:10.2307/255702, http://dx.doi.org/10.2307/255702

Hawes, M.J., \& Crittenden, F.W. (1984).A taxonomy of competitive retailing strategies, Strategic Management Journal, 5: 275-87. doi:10.1002/smj.4250050307, http://dx.doi.org/10.1002/smj.4250050307

Hodgkinson, G.P. (1997a).Cognitive Inertia in a turbulent market: the case of UK residential estate agents. Journal of Management Studies, $34 \quad$ (6).: 921-940. doi:10.1111/1467-6486.00078, http://dx.doi.org/10.1111/1467-6486.00078

Hodgkinson, G.P. (1997b).The Cognitive Analysis of Competitive Structure: A Review and Critique. Human Relations, 50 (6).: 625-654. doi:10.1177/001872679705000601, http://dx.doi.org/10.1177/001872679705000601

Hodgkinson, G., \& Johnson, G. (1994).Exploring the Mental Models of Competitive Strategists: The case for a processual approach. Journal of Management Studies, 31 (4).: 525-551. doi:10.1111/j.1467-6486.1994.tb00629.x, http://dx.doi.org/10.1111/j.1467-6486.1994.tb00629.x 
Holland, J.H., Holyoack, K.J., Nisbett, R.E., \& Thagard, P.R. (1986).Induction: Processes of inference, learning, and discovery. Cambridge, MA: MIT Press.

Huff, A.S., \& Schwenck, C. (1990).Bias and sensemaking in good times and bad. In A.S. Huff (Ed), Mapping Strategic Thought: 81-108. Chichester: Wiley.

Hunt, M.S. (1972).Competition in the major home appliance industry, 1960-1970, Unpublished doctoral dissertation, Harvard University.

James, G.E. (2000).Industry-Level Learning and the Social Construction of Recipes. In A.S.

Johnson, P., Daniels, K., \& Asch, R. (1998).Mental Models of Competition. In C. Eden \& J.C. Spender (Eds), Managerial and Organizational Cognition: Theory, Methods and Research: 130-146. London: Sage Publications.

Johnson, G. (1988).Re-Thinking Incrementalism. Strategic Management Journal, 9: 75-91. doi:10.1111/10.1002/smj.4250090107, http://dx.doi.org/10.1002/smj.4250090107

Kelly, G.A. (1955). The Psychology of Personal Constructs. New York: Norton.

Kahneman, D., \& Tversky, A. (1973).On the psychology of prediction. Psychological Review, 80: 237-257. doi:10.1037/h0034747, http://dx.doi.org/10.1037/h0034747

Kiesler, S., \& Sproull, L. (1982).Managerial response to changing environments: Perspectives on problem sensing from social cognition. Administrative Science Quaterly, 27: 548-570. doi:10.2307/2392530, http://dx.doi.org/10.2307/2392530

Lant, T.K., Milliken, F.J., \& Batra, B. (1992).The role of managerial learning and interpretation in strategic persistence and reorientation, An empirical exploration. Strategic Management Journal, 13(8).: 585-608. doi:10.1002/smj.4250130803, http://dx.doi.org/10.1002/smj.4250130803

Lawrence, P.R., \& Lorsch, J.W. (1967).Organizations and Environment: Managing Differenciation and Integration. Boston, MA: Graduate School of Administration, Harvard University.

Levenhagen, M., Porac, J.F., \& Thomas, H. (1993).Emergent Industry Leadership and the selling of technological visions: A social Constructionist View. In J. Hendry, G. Johnson \& J. Newton (Eds.), Strategic Thinking: Leadership and the management of change: 69-87, Chichester: Wiley.

Lyles, M.A., \& Schwenk, C. (1992).Top Management, Strategy and Organizational Knowledge Structure. Journal $\begin{array}{lllll}\text { of } M a n a g e m e n t & \text { Studies, } 29 & \text { (2).: } & 155-174 . & \text { doi:10.1111/j.1467-6486.1992.tb00658.x, }\end{array}$ http://dx.doi.org/10.1111/j.1467-6486.1992.tb00658.x

Mitroff, I. (1988).Crisis Management: Cutting through the Confusion. Sloan Management review, 29: 15-20.

Murphy, G.L., \& Wright, J.C. (1984).Changes in Conceptual Structure with Expertise: Differences between real-world experts and novices. Journal of Experimental Psychology: Learning, Memory and Cognition, 10(1).: 144-155. doi:10.1037/0278-7393.10.1.144, http://dx.doi.org/10.1037/0278-7393.10.1.144

Narayanan, V.K., \& Kemmerer, B. (2001).The cognitive perspective on Strategic Management: Contributions, Challenges and Implications. Paper presented at the 2001 Academy of Management Annual Meeting, Washington, DC.

Narayanan, V.K., \& Fahey, L. (1990).Evolution of revealed causal maps during decline: A case study of Admiral. In A.S. Huff, Mapping Strategic Thought: 109-133. Chichester: Wiley.

Newman, H. (1978).Strategic Group and The Structure Performance Relationship. Review of economics and Statistics, 60: 417-427. doi:10.2307/1924167, http://dx.doi.org/10.2307/1924167

Nystrom, P.C. \& Starbuck, W.H. (1984).To Avoid Organizational Crisis: Unlearn. Organizational Dynamics, Spring, 53-65. doi:10.1016/0090-2616(84)90011-1, http://dx.doi.org/10.1016/0090-2616(84)90011-1

Oster, S. 1982. Intraindustry structure and the ease of strategic change. Review of economics and Statistics, 64: 376-83. doi:10.2307/1925935, http://dx.doi.org/10.2307/1925935

Peteraf, M., \& Shanley, M. (1997).Getting to know you: a theory of strategic group identity. Strategic Management Journal, 18 (Summer Special Issue).: 165-186.

Porac, J.F., Thomas, H., Wilson, F., Paton, D., \& Kanfer, A.. 1995. Rivalry in the industry model of Scottish Knitwear producers. Administrative Science Quaterly, 40: 203-227. doi:10.2307/2393636, http://dx.doi.org/10.2307/2393636

Porac, J.F., \& Thomas, H., (1990).Taxonomic Mental Models in Competitor Definition. Academy of Management Review, 15 (2).: 224-240. 
Porac, J.F., Thomas, H., \& Baden-Fuller, C. (1989).Competitive groups as cognitive communities: the case of Scottish knitwear manufacturers. Journal of Management Studies, 26 (4).: 397-416. doi:10.1111/j.1467-6486.1989.tb00736.x, http://dx.doi.org/10.1111/j.1467-6486.1989.tb00736.x

Porac, J.F., Thomas, H., \& Emme, B. (1987).Understanding strategists' mental models of competition. In G. Johnson (Ed), Business Strategy and Retailing: 59-79. New York and Chichester: Wiley.

Porter, M.E. (1980).Competitive strategy. New York: Free Press.

Reger, K., \& Palmer, T.B. (1996).Managerial Categorization of Competitors: Using Old Maps to Navigate New Environments. Organization Science, 7 (1).: 22-39. doi:10.1287/orsc.7.1.22, http://dx.doi.org/10.1287/orsc.7.1.22

Reger, K., \& Huff, A.S. (1993).Strategic Groups: A cognitive perspective. Strategic Management Journal, 14: 103-124. doi:10.1002/smj.4250140203, http://dx.doi.org/10.1002/smj.4250140203

Reger, K. (1990).Managerial thought structures and competitive positioning. In A.S. Huff, Mapping Strategic Thought: 71-88. Chichester: Wiley.

Rosch, E. (1981).Prototype classification and logical classification: The two systems. In E. Scholnick (Ed.), New trends in cognitive representation: Challenges to Piaget's theory: 73-86. Hillsdale, NJ: Erlbaum.

Rosch, E. (1978).Principles of categorization. In E. Rosch \& B. Lloyd (Eds), Cognition and categorization: 27-48. Hillsdale, NJ: Erlbaum.

Rumelt, R.P. (1987).Theory, strategy, and entrepreneurship. In D.J. Teece (Ed.), The competitive challenge: 137-158. Cambridge, MA: Ballinger.

Schneider, S.C., \& de Meyer, A. (1991).Interpreting and responding to Strategic Issues: The impact of national structure. Strategic Management Journal, 12 (4).: 307-320. doi:10.1002/smj.4250120406, http://dx.doi.org/10.1002/smj.4250120406

Schoenfled, A.H., \& Herrman, D.J. (1982).Problem Perception and Knowledge Structures in Expert and Novice Mathematical Problem Solvers. Journal of experimental Psychology: Learning, Memory and Cognition, 5: 484-494. doi:10.1037/0278-7393.8.5.484, http://dx.doi.org/10.1037/0278-7393.8.5.484

Secrétariat d'Etat Français au Tourisme. (2002).Le marché du voyage et la grande distribution.

Slywotzky, A.J. (1996).Value migration. Boston, MA: Harvard Business School Press.

Smith, E.E., \& Medin, D.L. (1981).Categories and concepts. Cambridge, MA: Harvard University Press.

Spender, J.C. (1989).Industry Recipes: An Enquiry into the Nature and Sources of Managerial Judgement. Oxford: Blackwell.

Starbuck, W.K. (1975).Information systems for organizations of the future. In E. Grochla \& N. Szyperski (Eds), Information Systems and Organizational Structure: 217-229. De Gruyter: Berlin.

Sutcliffe, K.M. (1994). What Executives Notice: Accurate perceptions in top management teams. Academy of Management journal, 37(5): 1360-1378. doi:10.2307/256677, http://dx.doi.org/10.2307/256677

Tanaka, J.W., \& Taylor, M. (1991).Object categories and expertise: Is the basic level in the eye of the beholder ?. Cognitive psychology, 23: 457-482. doi:10.1016/0010-0285(91)90016-H, http://dx.doi.org/10.1016/0010-0285(91)90016-H

Walton, E. (1986).Managers' prototypes of financial firms. Journal of Management Studies, 23: 679-98. doi:10.1111/j.1467-6486.1986.tb00442.x, http://dx.doi.org/10.1111/j.1467-6486.1986.tb00442.x

Whitley, R. (1987).Taking Firms seriously as Economic Actors: Towards a Sociology of Firm Behaviour.

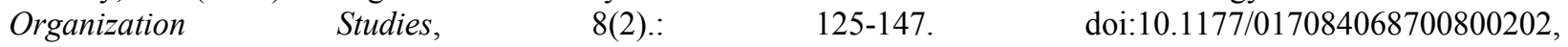

http://dx.doi.org/10.1177/017084068700800202

Table 1. Cognitions on newcomers

\begin{tabular}{|c|c|c|c|c|c|c|}
\hline \multirow[b]{2}{*}{$\begin{array}{l}\text { Average competitive } \\
\text { cognitions }\end{array}$} & $\begin{array}{c}\text { Foreign } \\
\text { Tour-operators }\end{array}$ & \multicolumn{2}{|c|}{ Only web-based organizations } & \multicolumn{3}{|c|}{ Mass Merchandisers } \\
\hline & Current & Anticipated & Current & Anticipated & Current & Anticipated \\
\hline Wide & 3,1 & 2,4 & 3,4 & 3,2 & 3,7 & 3,6 \\
\hline Close & 4,4 & 4 & 4,8 & 4,8 & 4,9 & 4,9 \\
\hline
\end{tabular}

